\title{
Nest site selection and nesting behavior of the mud turtle Kinosternon scorpiodes (Testudines, Kinosternidae) in Palo Verde National Park, Costa Rica: implications for management
}

\author{
José M. Mora ${ }^{1,2}$, Franklin E. Castañeda ${ }^{3}$ \\ 1 Carrera de Gestión Ecoturística, Sede Central y Unidad de Ciencias Básicas, Sede Atenas, Universidad \\ Técnica Nacional, Alajuela, Costa Rica \\ 2 Department of Biology and Museum of Vertebrate Biology, Portland State University, Portland, Oregon \\ 97207, USA \\ 3 Fundación Panthera, Tegucigalpa, Honduras
}

Corresponding author: José Manuel Mora (jomora@pdx.edu)

Academic editor: A. M. Leal-Zanchet | Received 13 November 2020 | Accepted 24 April 2021 | Published 12 May 2021

Citation: Mora JM, Castañeda FE (2021) Nest site selection and nesting behavior of the mud turtle Kinosternon scorpiodes (Testudines, Kinosternidae) in Palo Verde National Park, Costa Rica: implications for management. Neotropical Biology and Conservation 16(2): 273-287. https://doi.org/10.3897/neotropical.16.e60754

\begin{abstract}
Habitat selection is the process whereby individuals preferentially use, or occupy, a non-random set of available habitats. At the same time, nest site selection is defined as the placement of eggs by females at sites differing from random sites within a delimited area. We located 59 nests of the mud turtle Kinosternon scorpioides in Palo Verde National Park (PVNP) in Northwestern Costa Rica. We compared eight microhabitat variables at nest sites against those at random sites. Females significantly placed their eggs at sites with more understory, leaf litter cover, and greater leaf litter depth than in random sites. Additionally, females selected sites with lower air and soil temperature and lower air humidity. Palo Verde NP is subject to active management actions designed to control invasive plant species in the wetland, namely cattail (Thypha domingensis Pers.). The main actions have been cattle grazing, controlled fires, and mechanical crushing of vegetation. We found that habitat quality in nesting areas is being threatened by at least one of these actions: cattle grazing. This is detrimental for three microhabitat traits that turtles select for nesting sites: understory cover, leaf litter cover, and leaf litter depth. The continued degradation of microhabitats at nesting areas of $K$. scorpioides at PVNP could be affecting recruitment due to embryo survivorship.
\end{abstract}




\section{Keywords}

Cattle, habitat management, habitat selection, predation, wetland

\section{Introduction}

Variation in abundance and distribution of a species is often determined by suitable habitat availability, which must include all necessary components to ensure the species survival: food, water, refuge, and reproductive sites (Litvaitis et al. 1994). Habitat selection is the process whereby individuals preferentially occupy a nonrandom subset of available habitats (Morris 2003). Nest site selection is defined as the placement of eggs by females at sites with different characteristics from random sites within a delimited area (Wilson 1998). Such behavior may reduce both egg predation and exposure to environmental extremes (Wilson 1998) which consequently leads to increased embryo development and survival rates. For turtles and many other animals, nest predation is a major cause of reproductive failure (Oddie et al. 2015; Voves et al. 2016), making nest site selection an important component of fitness. As a result, maternal site selection represents a critical component of nest success (Mui et al. 2016).

Nest site selection has been documented for several species of turtles, among them Carettochelys insculpta (Doody et al. 2003), Chelydra serpentina (Kolbe and Janzen 2001), Chrysemys picta bellii (Janzen 1994), Emydura macquarii (Spencer and Thompson 2003), Kinosternon baurii, Kinosternon subrubrum, and Pseudemydura umbrina (Wilson 1998). The importance of the structural characteristics of the environment surrounding the nest and their influence on survival rate, hatchling size, and sex ratios have been documented by several field and laboratory studies (e.g. Burke et al. 2005; Eggers et al. 2008; Strickland et al. 2010; Wirsing et al. 2012; Voves et al. 2016). For instance, the humidity of the incubation environment influences embryo size, and larger hatchlings appear to be more successful escaping predation and surviving the first year of life (Packard et al. 1987). However, the survival of hatchling snapping turtles was not dependent on body size (Congdon et al. 1999). Thus, variation in nest site humidity could lower hatchling survival rate. Also, in species with temperature-dependent sex determination (TSD), sex ratios can be skewed as a result of habitat alteration on nesting areas (Janzen 1994, Butler et al. 2016). For instance, areas stripped of vegetation might produce more females because of a higher incubation temperature (Vogt and Flores-Villela 1992). Hence, habitat alterations that affect nesting areas could have a severe impact on freshwater turtle populations (Vogt and Flores-Villela 1992).

Palo Verde National Park (PVNP), in northwestern Costa Rica, is one of the few national protected areas that is legally subject to habitat changes caused by human actions (active management) such as cattle grazing, controlled fires, and mechanical crushing of vegetation (Castañeda and Mora 2010). The purpose of these actions is to create and maintain areas of open waters favorable to wintering waterfowl, and to reduce risk of wild fires (Burnidge 2000; Barboza 2002; MINAE 2002). There has 
been an invasion of the cattail (Typha domingensis Pers.) to the wetlands of the area due to chemical pollutants in the water produced by several crops that surround the area (Burnidge 2000). While bird populations are monitored to assess their response to changes in resource availability (i.e., habitat characteristics), no information is available on the impact of these management actions on other vertebrate species within the park with some exceptions (Castañeda and Mora 2010).

Comparing available resources to utilized resources allows for the validation of conclusions concerning habitat selection (Manly et al. 2002). When resources are used disproportionately compared to their availability, the resource use is selective (Manly et al. 2002). The comparison of the physical structure of nesting locations with that of random sites within a delimited area is especially useful in identifying the characteristics of the habitat that determine nest site selection (Wilson 1998; Kolbe and Janzen 2002). In this paper, we compare several microhabitat variables at nest sites of Kinosternon scorpiodes against those at random sites in the nesting area within PVNP. We analyze how active management of this protected area is changing the habitat structure of nesting areas and the possible impact on the population. In addition, we provide information on female nesting behavior, clutch size and nesting female size.

\section{Methods}

\section{Study species}

Kinosternon scorpioides is a small species of freshwater turtle widely distributed in Central and South America, including the Pacific slope of Costa Rica (Leenders 2019). The species is relatively large for the genus and it has been shown to vary in both total size and sexual size dimorphism (Mota Rodrigues and Borges-Nojosa 2013; Bedoya-Cañón et al. 2018). During nesting, females excavate a nest 2.1$4.6 \mathrm{~cm}$ deep and lay around six hard, brittle-shelled eggs (Iverson 2010; Castañeda and Mora 2015). Eggs are $40 \times 19 \mathrm{~mm}$ in length and width, and hatchlings are 30-40 mm carapace length. Incubation takes from 115 to 128 days (Acuña 1998; Savage 2002). Temperature-dependent sex determination with pattern II (TSD-II) has been reported for at least six species in the family Kinosternidae, including $K$. scorpioides (Ewert and Nelson 1991; Janzen and Krenz 2004). TSD-II produces females at low and high temperatures and males at intermediate temperatures (De La Ossa et al. 2014). Little information is available on the reproduction of $K$. scorpioides in general (Fernandes Araujo Chaves et al. 2020), and microhabitat characteristics of their nests in particular (Bedoya-Cañón et al. 2018). Although K. scorpioides is a turtle with a wide ecological tolerance, capable of inhabiting almost any body of shallow water, it likes to live in places with abundant aquatic vegetation (RuedaAlmonacid et al. 2007). Copulation takes place on land or in shallow water, and nests are usually excavated at the base of masses of grasses or shrubs up to $200 \mathrm{~m}$ from bodies of water (Rueda-Almonacid et al. 2007). 


\section{Study site}

We conducted our research in Palo Verde National Park (PVNP), located in the northwestern lowlands of Guanacaste Province, Costa Rica (10² $21^{\prime} \mathrm{N}, 85^{\circ} 21^{\prime} \mathrm{W}$; Fig. 1). The park extends over an area of 19800 ha; average temperature was $27^{\circ} \mathrm{C}$, and annual precipitation was $2296 \mathrm{~mm}$ (Castañeda and Mora 2010). The dry season lasts from December to April and the rainy season from May to November. A great variety of habitats are represented in PVNP: primary and secondary deciduous dry forest, riparian forest, savannas and wetlands (Hartshorn 1983; Mora 1989). The study area was located between the facilities of the Organization for Tropical Studies (OTS) and those of the Palo Verde MINAE station (Fig. 1). Sampling effort was concentrated in an area of 4 ha of old secondary dry forest adjacent to the Palo Verde marsh.

\section{Nesting behavior, nest location and microhabitat variables}

We measured body size, number of eggs, and egg size of nesting K. scorpioides females from October 2003 to November 2004. For each female, we measured curved carapace length (CCL) to the nearest $0.1 \mathrm{~cm}$ with a flexible measuring tape, and body mass with a $1000 \mathrm{~g}$ capacity spring scale. We measured egg length and width to the nearest $0.1 \mathrm{~cm}$ using $152 \mathrm{~mm}$ metal calipers, and body mass using a $30 \mathrm{~g}$ capacity spring scale. Data reported as mean \pm SE.

We located K. scorpioides nests and measured microhabitat characteristics during February and March 2004. Because nests were cryptic and difficult to find, we located nests by either following emerging females to their nest sites, raking leaf litter, or observation of the white eggshells exposed by nest predators. To test for nest site selectivity, we searched the 4-ha study area along six transects of a $200 \mathrm{~m}$ length. We located a random site every $10 \mathrm{~m}$ along each transect (site without nest). We compared the values of eight microhabitat variables measured at nest sites to those measured at random sites to see if nest sites were different. We measured canopy cover with a spherical densiometer (Forestry Suppliers Spherical Crown Densiometer, Concave Model C). For this study, we considered all shrubby and herbaceous vegetation from 0.1 to $1.5 \mathrm{~m}$ above the ground as understory cover. We measured these two variables by centering a $1-\mathrm{m}^{2}$ grid at each site. We visually estimated the percentage of ground covered by leaf litter at each of these grids. We used a $35 \times$ $20 \mathrm{~cm}$ wooden board marked with 10 circles of $3 \mathrm{~cm}$ in diameter to estimate horizontal understory cover. We placed the board above the ground at a distance of $1 \mathrm{~m}$ from the sites and took two measures, one to the north and one to the south. We counted the number of circles that the vegetation allowed us to see through at $20 \mathrm{~cm}$ above the ground (methodology modified from Higgins et al. 1994). We measured leaf litter depth with a metal ruler. We used a digital hygro-thermometer (model 445582 Extech Instruments) to measure air temperature and air humidity. We located the hygro-thermometer $5 \mathrm{~mm}$ above the ground in the shade at each nest 


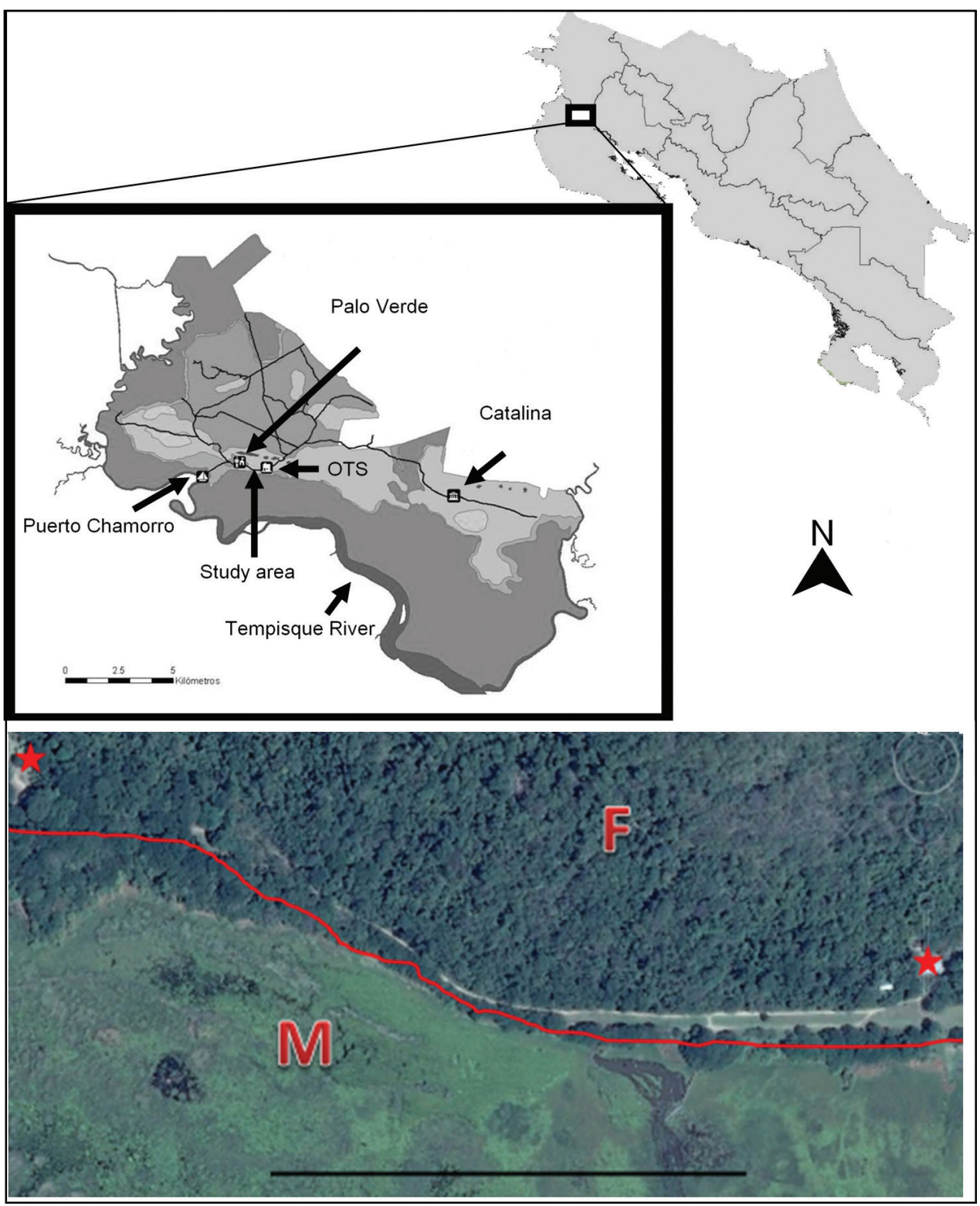

Figure 1. Palo Verde National Park in northwestern Costa Rica (above). The study area (below) depicts the limit between the Palo Verde marsh (M) and the forest (F). A barbed wire fence (red line approximately) runs in between the forest and the marsh parallel to the road between the Palo Verde MINAE station (star at left) and the OTS station (star at right). Black line $=1 \mathrm{~km}$ (approximately).

site and each random site and took the reading after $5 \mathrm{~min}$. We measured the soil temperature at $5 \mathrm{~cm}$ depth using a thermometer (HI-145-30 Hanna Instruments); we took the reading after $5 \mathrm{~min}$. 
To test for differences in microhabitat variables between nest sites and random sites we analyzed the data using a Multivariate Analysis of Variance (MANOVA). We used a 2-sample t-test to test for differences among each variable. We analyzed the data using JMPin 4.0.4 and Systat 9.0.

To eliminate the effect of temperature variation throughout the day, we took all temperature measurements used to compare nest sites and random sites from 1200 to $1400 \mathrm{~h}$ (the warmest hours of the day). To better estimate the nest average temperature throughout the day, we also took nest temperatures from 0500 to $0700 \mathrm{~h}$ (the coolest hours of the day). We chose these hours after reviewing the data provided by the OTS weather station. At the same time, we tested for differences in average ambient temperature on days in which we took nest and random site temperatures. We analyzed environmental temperature data from the OTS weather station using a one-way Analysis of Variance (ANOVA).

\section{Areas under cattle grazing vs areas free of cattle grazing}

The study area ( 4 ha) is divided by a fence running east - west (Fig. 1). The park's administration uses the fence to keep the cattle in the wetland and out of the forest. However, the fence runs inside the forest at $0-15 \mathrm{~m}$ from the wetland border, resulting in two treatments within the same nesting area and habitat: 1) areas under cattle grazing and 2) areas free of cattle grazing (Fig. 2). In order to test for microhabitat differences between treatments, we placed 144 plots of $1 \mathrm{~m}^{2}$ each at random sites inside and outside the fence (72 plots per treatment). We measured three microhabitat variables on every plot: understory cover, leaf litter cover, and leaf litter depth. We tested for differences between both treatments (area with cattle grazing and area free of cattle grazing) with the Mann-Whitney $\mathrm{U}$ test. We arcsine transformed all percentage data before we conducted any analyses (Zar 1999).

\section{Results}

\section{Nesting behavior}

We observed Kinosternon scorpiodes females nesting during February, October and November. We also assumed in March evidence of nesting activity such as fresh mud accumulation on female's posterior marginal scutes. Females left the water and walked straight into the forest. Once under the forest canopy females spent $1-1.5 \mathrm{~h}$ moving erratically in areas of about $15 \times 15 \mathrm{~m}$, apparently searching for a suitable site to nest. During this search, females dig with their front legs into the leaf litter and place their snouts on the ground (ground-nuzzling), move a few meters and repeat these actions. This behavior lasted until the turtle finally began to dig a nest with its hind legs. The nest digging process took between 1 to $1.5 \mathrm{~h}$. Some females dug their nest while their shells were completely covered with 


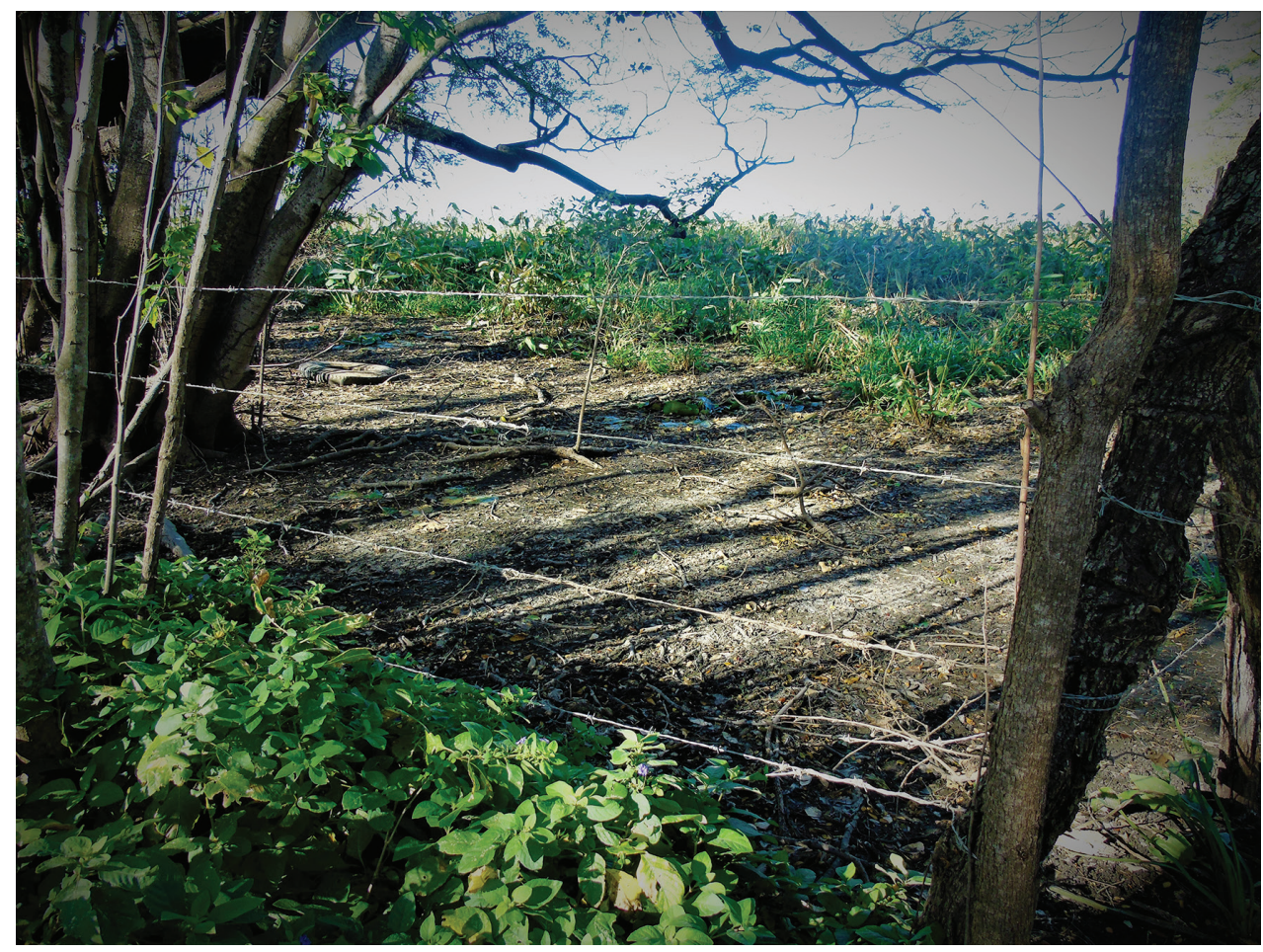

Figure 2. A barbwire fence running east - west at Palo Verde National park in northwestern Costa Rica divides the study area and keep the cattle in the wetland and out of the forest. The area at the forest side maintains vegetation but cattle eat understory plants at the marsh side (bare soil). Photo: José Manuel Mora.

leaves. We found 14 out of 102 females on land during the study period with mud accumulation on the posterior marginal scutes and occasionally also on the anal scutes after completion of nesting. Five of the 14 females were found while nesting (Fig. 3). We did not find mud accumulation or dirt in juvenile turtles $(\mathrm{n}=29)$, or adult males $(\mathrm{n}=42)$.

We found active nesting females from $0700-1100 \mathrm{~h}$ and from $1500-2300 \mathrm{~h}$. Nesting females have an average of carapace length (CCL) of $18.41 \pm 0.28 \mathrm{~cm}$ (range $16.6-19.9 \mathrm{~cm}, \mathrm{n}=14$ ) and average weight after nesting of $670 \pm 32.9 \mathrm{~g}$ (range 460 $790, \mathrm{n}=14)$. Nesting females observed at Palo Verde in this study laid between three and eight eggs per nest $(n=14)$. We found a positive relationship between the number of eggs and female CCL $\left(\mathrm{r}^{2}=0.73, \mathrm{P}=0.06\right)$. The eggs averaged a length of 3.26 $\pm 0.16 \mathrm{~cm}(\mathrm{n}=35)$, egg width averages $=1.79 \pm 0.06 \mathrm{~cm}(\mathrm{n}=35)$, egg mass average $=$ $6.34 \pm 0.74 \mathrm{~g}(\mathrm{n}=16)$. We saw one hatchling actively moving over land in May 2004; this individual measured $2.7 \mathrm{~cm}$ standard carapace length, $2.1 \mathrm{~cm}$ standard carapace width and weighed $4.25 \mathrm{~g}$. We collected two egg clutches as vouchers in November 2004 and deposited them at the museum of zoology of the University of Costa Rica (clutch of three eggs UCR 17395; clutch of seven eggs UCR 17396). 


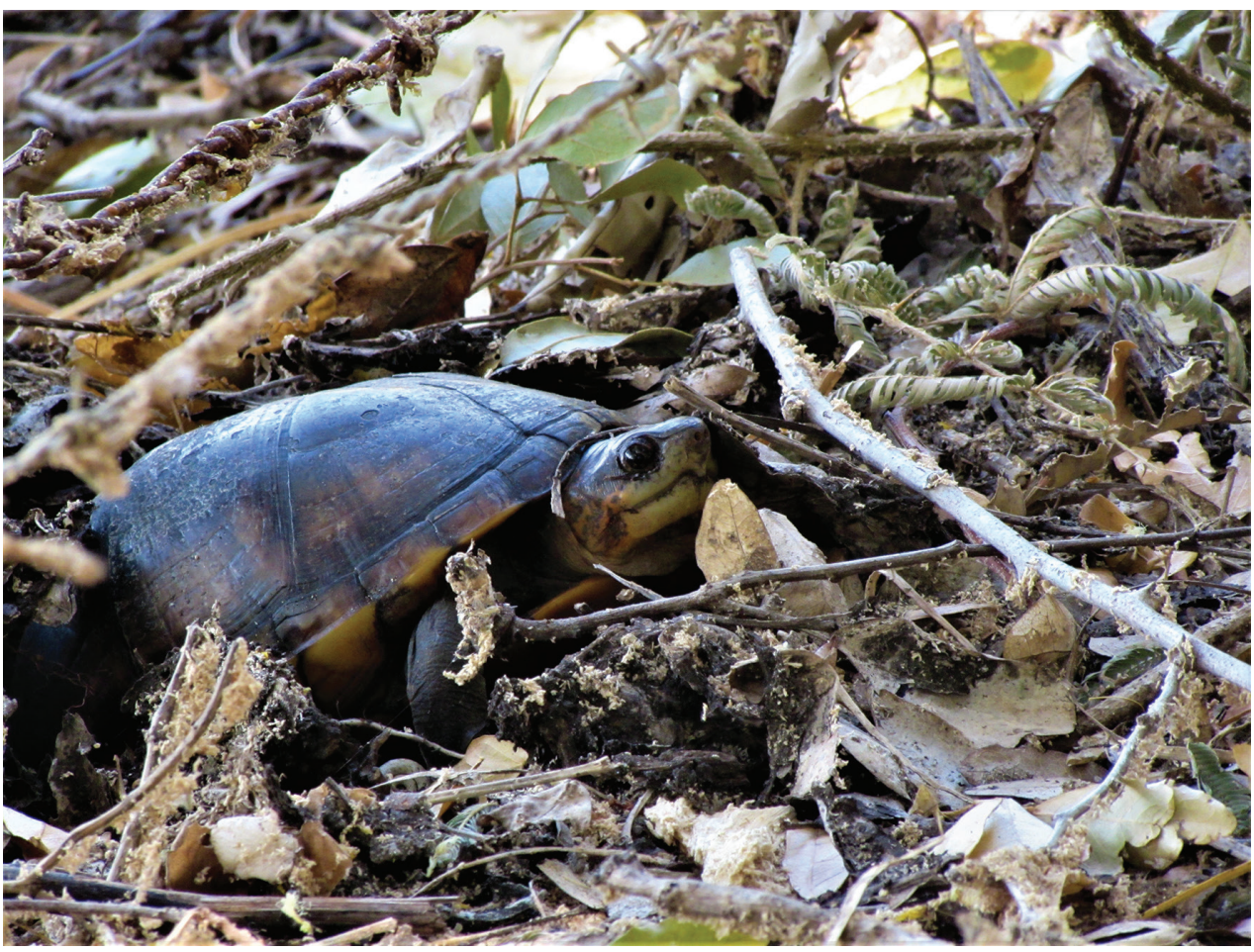

Figure 3. A female mud turtle (Kinosternon scorpiodes) nesting at Palo Verde National Park, northwestern Costa Rica. Note the barbwire of the fence above the turtle. Photo: José Manuel Mora.

\section{Nest location and microhabitat variables}

We did not find any nests in open areas or the wetland border, which was dry and covered with aquatic plants, or in grass tussocks during the dry season. We found all nests under the forest canopy. We found nests at distances that ranged from 5 to $175 \mathrm{~m}$ from the water line. We found most nests during the dry season in the first 5 to $50 \mathrm{~m}$ of forest from the water line. However, during the wet season we found nests at greater distances (up to $175 \mathrm{~m}$ ) from the wetland.

We compared 59 nest sites with 54 random sites (some sites had more than one nest). Females placed their eggs at sites that differed from random sites $\left(\mathrm{F}_{8,90}=11.2\right.$, $\mathrm{P}<0.0001$ ) in at least seven of the eight variables of microhabitat under analysis (Table 1). Horizontal understory cover was the only variable that shows no differences between nest sites and random sites (Table 1). It appears females select sites with more understory cover, more leaf litter cover, greater leaf litter depth, and less dense canopy cover than the random sites (Table 1).

When we analyzed the temperature readings from the OTS weather station, we did not find significant differences in average environmental temperature on days of sampling $\left(\mathrm{F}_{5,168}=0.87, \mathrm{P}=0.50\right)$. This indicates that the environmental temperature in 
Table 1. Mean and standard error of the eight variables of microhabitat measured at nest sites and at random sites in a Kinosternon scorpioides nesting area in Palo Verde National Park, Northwestern Costa Rica. T and P values of paired comparisons are also given. For each microhabitat variable, the sample size (n) in parenthesis.

\begin{tabular}{lcccc}
\hline \multicolumn{1}{c}{ Microhabitat variables } & Nest sites & Random sites & $\boldsymbol{T}$ & P \\
\hline Canopy cover $(\%)$ & $90.4 \pm 0.89(56)$ & $93.7 \pm 0.70(54)$ & $t_{109.95}=-2.86$ & $<0.005$ \\
Understory cover (\%) & $42.80 \pm 3.24(56)$ & $31.29 \pm 3.41(54)$ & $t_{109.95}=2.44$ & $=0.01$ \\
Leaf litter cover $(\%)$ & $90.70 \pm 1.85(56)$ & $84.35 \pm 1.88(54)$ & $t_{109.95}=2.39$ & $=0.01$ \\
Leaf litter depth $(\mathrm{cm})$ & $3.04 \pm 0.23(55)$ & $2.0 \pm 0.15(51)$ & $t_{105.95}=3.68$ & $<0.001$ \\
Horizontal understory cover $(\%)$ & $27.76 \pm 2.9(55)$ & $25.94 \pm 3.25(53)$ & $t_{107.95}=0.42$ & $=0.67$ \\
Air temperature $\left({ }^{\circ} \mathrm{C}\right)$ & $34.82 \pm 0.17(52)$ & $35.55 \pm 0.21(53)$ & $t_{104.95}=-2.62$ & $=0.01$ \\
Air humidity $(\%)$ & $43.29 \pm 0.55(52)$ & $45.75 \pm 0.80(52)$ & $t_{103.95}=-2.53$ & $=0.01$ \\
Soil temperature $\left({ }^{\circ} \mathrm{C}\right)$ & $28.13 \pm 0.12(53)$ & $29.04 \pm 0.14(53)$ & $t_{105.95}=-4.74$ & $<0.001$ \\
\hline
\end{tabular}

the study area was homogeneous throughout the days in which temperature readings were taken at nest and random sites. Nest sites had lower air and soil temperature and lower air humidity (Table 1). Average soil temperature at nest sites was $28.13^{\circ} \mathrm{C}$ from 1200 to $1400 \mathrm{~h}$, and $26.40^{\circ} \mathrm{C}$ from 0500 to $0700 \mathrm{~h}$, with an overall average of $27.26^{\circ} \mathrm{C}$. Leaf litter depth was negatively correlated with soil temperature (Pearson $r=-0.35$ ), and air temperature was negatively correlated with air humidity (Pearson $r=-0.57)$.

\section{Areas under cattle grazing vs areas free of cattle grazing}

We found only two nests in areas under cattle grazing (3.4\% of total nests found, $\mathrm{n}=59$ ). However, outside the fence (no cattle grazing) we found 43 nests $1-10 \mathrm{~m}$ from the fence (72.9\%). We also found six nests right under the fence (10.2\%), for example the female in Figure 3. We found only $13.5 \%$ of the nests (8) at distances greater than $10 \mathrm{~m}$ from the fence. We found significant differences between treatments in all three variables measured. Areas outside the fence had higher percentage of understory cover $(\mathrm{U}=412, \mathrm{P}<0.0001)$, leaf litter cover $(\mathrm{U}=864, \mathrm{P}<0.0001)$, and greater leaf litter depth $(\mathrm{U}=895, \mathrm{P}<0.0001)$. The understory cover inside the fence was almost nonexistent in areas with cattle grazing and both leaf litter variables were lower.

\section{Discussion}

We found that average carapace length (CCL) of nesting Kinosternon scorpiodes at Palo Verde is higher than the most common size of $15 \mathrm{~cm}$ previously reported for this species (Rueda-Almonacid et al. 2007). This CCL average correlates positively with the number of eggs laid by this species at Palo Verde. The number of eggs observed by us appears to be within the range observed in other populations of this species (Rueda-Almonacid et al. 2007; Castañeda and Mora 2015). However, average egg size at Palo Verde was slightly smaller than the previously reported average (Acuña 1998; Savage 2002; Rueda-Almonacid et al. 2007). We do not have the raw data to undertake a metanalysis, but it is important to note that kinosternids display 
remarkable amounts of morphological crypsis, with numerous novel species being described recently (e.g. Scott et al. 2018, Loc-Barragán et al. 2020). Differences between and among dispersed populations in characters as important as egg size therefore may be indicative of more substantial underlying biological differences. In the case of our study population, our results with respect to egg length match those of Acuña (1998), but reflect a reduction of 36\% with respect to other Costa Rican populations (Savage 2002) and 18\% compared to Transandean populations (RuedaAlmonacid et al. 2007). These outsize differences may be worth examining further from a taxonomic perspective.

With respect to development, it is important to note that females appear to be selecting nesting sites with more understory cover, more leaf litter cover, greater leaf litter depth, and less dense canopy cover than the random sites (Table 1). This points to a selection of nesting sites on the part of females that have the potential to improve the reproductive potential of females because choice of nesting site at both the micro- and the macro-habitat level can be critical for turtle breeding success (Spencer and Thompson 2003). Although at least some components of nestsite selection must have a genetic basis to enable evolutionary selection (Kolbe and Janzen 2002), in the particular instance of K. scorpiodes at Palo Verde, the key point is that conditions favorable to continued reproductive success and egg development should be maintained and assured.

Semlitsch and Bodie (2003) found, from a literature review, that terrestrial habitats are important for amphibians and reptiles associated with wetlands for feeding, overwintering and nesting. Thus, the healthy biological interdependence between aquatic and terrestrial habitat is essential for the persistence of populations (Semlitsch and Bodie 2003). Upland habitats adjacent to wetlands are critical to nesting in freshwater turtles (Steen et al. 2012). To protect 100\% of the nests and hibernation sites for three species of freshwater turtles (Kinosternon subrubrum, Pseudemys floridana and Trachemys scripta), a core area that extends $275 \mathrm{~m}$ beyond the wetland is needed (Burke and Gibbons 1995). However, the core area needed is variable according to species habits among other factors (Steen et al. 2012). We found K. scorpioides nests at PVNP as far as $175 \mathrm{~m}$ from the wetlands, and Acuña (1998) reported nests up to $200 \mathrm{~m}$ from the wetlands in the same area. To protect $100 \%$ of the K. scorpioides nests at PVNP, the core area needs to be $175 \mathrm{~m}$ from the wetland. However, to protect $86.4 \%$ of the nests, the core area would only have to extend $25 \mathrm{~m}$ from the wetland. These data should be considered to protect core areas around wetlands elsewhere in Costa Rica. Nesting areas are important components of an egg-laying species habitat and need to be considered in conservation plans (Ficetola et al. 2004). Within protected natural areas, successful management actions can only be achieved if the components of habitat quality, including nesting habitat, are well understood.

Gravid females are selective in terms of nesting sites. This behavior is an important determinant of offspring success (López et al. 2013). This means, that in order to guarantee the successful reproduction of $K$. scorpioides, certain habitat characteristics must be available in the areas comprising the first few meters of 
terrestrial habitat surrounding the wetland. However, there are many unanswered questions pertaining to how habitat preferences may influence turtle nesting migrations (Steen et al. 2012). Some of the basic characteristics of successful nests should include well-drained, and sparsely vegetated, loose sandy soil with low vegetation cover as has been suggested for other species (Hughes and Brooks 2006; Dowling et al. 2010). Thus, it is the quality of habitat available that matters and not only its quantity in this particular case.

We found that habitat quality at nesting areas is being threatened by at least one of the active management actions in the park, i.e., cattle grazing. Livestock are changing the understory structure by destroying all shrubby vegetation and modifying the leaf litter cover and depth within the first 10 to $15 \mathrm{~m}$ of forest from the wetland. This is detrimental for three microhabitat traits that $K$. scorpioides females select for nesting sites: understory cover, leaf litter cover, and leaf litter depth. Indeed, the large differences found in vegetation structure between areas with cattle grazing (inside the fence near the wetland) and areas free of grazing (Fig. 2), almost explain the total lack of nests in the first 10 to $15 \mathrm{~m}$ from the wetland and the great abundance of nests just across past the fence, which indicate that gravid females avoid nesting in the cattle grazing area, or they are not able to do so there. Additionally, the contrast between nests and their surrounding substrates could be a visual cue for predators to locate nests (Voves et al. 2016).

\section{Conclusions}

According to our results, Kinosternon scorpiodes enjoys good biological and ecological conditions for its survival at Palo Verde National Park. We provide data on specific microhabitat traits that characterize nesting areas of $K$. scorpiodes at this park in Northwestern Costa Rica. However, these traits are apparently being negatively affected by cattle grazing, one of the management actions conducted in the park. Since the main idea of having cattle within the wetland in PVNP is to reduce the amount of invasive aquatic plants in the marsh, there is no need to have the fence running 10 to $15 \mathrm{~m}$ within the dry forest. Instead, the fence should be moved and placed at the edge between the marsh and the forest. Doing this, cattle would be confined to the wetland and precluded from disturbing the core nesting area for female K. scorpioides. A lack of suitable nesting areas may be a primary reason for the absence of recruitment to a turtle population (Hughes et al. 2016). However, in addition to K. scorpioides, many other species of amphibians and reptiles at PVNP may depend upon the natural integrity of the ecotone between the marsh and the dry forest.

\section{Acknowledgements}

JMM acknowledges Emilce Rivera, department head, Carrera de Gestión Ecoturística, Sede Central, Universidad Técnica Nacional (UTN), and Daniel Tobias, co- 
ordinator, Unidad de Ciencias Básicas, Sede Atenas, UTN, for their support and time provided to complete this work. Both authors thank Paul Stone, Tiago Silva, Luis Ruedas, and two anonymous reviewers for their corrections and suggestions to improve this paper.

\section{References}

Acuña R (1998) Las tortugas continentales de Costa Rica. $2^{\text {nd }}$ edn. Universidad de Costa Rica, San José, Costa Rica, 92 pp.

Barboza J (2002) El pastoreo en la restauración del bosque tropical seco: Parque Nacional Palo Verde, Guanacaste, Costa Rica. Seminario Nov 13-15 2002. Universidad Nacional / INISEFOR, Heredia, Costa Rica.

Bedoya-Cañón MA, Muñoz-Avila JA, Vargas-Salinas F (2018) Morphology and natural history of the mud turtle Kinosternon scorpioides scorpioides in populations of northern Colombia. Herpetological Review 49(2): 210-214.

Burke V, Gibbons J (1995) Terrestrial buffer zones and wetland conservation: A case study of freshwater turtles in a Carolina bay. Conservation Biology 9(6): 1365-1369. https:// doi.org/10.1046/j.1523-1739.1995.09061365.x

Burke RL, Schneider CM, Dolinger MT (2005) Cues used by raccoons to find turtle nests: Effects of flags, human scent, and Diamond-backed Terrapin sign. Journal of Herpetology 39(2): 312-315. https://doi.org/10.1670/199-03N

Burnidge W (2000) Cattle and the management of freshwater neotropical wetlands in Palo Verde National Park, Guanacaste, Costa Rica. MSc thesis, Ann Arbor, Michigan: University of Michigan.

Butler CJ, Stanila BD, Iverson JB, Stone PA, Bryson M (2016) Projected changes in climatic suitability for Kinosternon turtles by 2050 and 2070. Ecology and Evolution 6(21): 7690-7705. https://doi.org/10.1002/ece3.2492

Castañeda FE, Mora JM (2010) Impact of fire on a wetland population of the Scorpion Mud Turtle (Kinosternon scorpioides) in northwestern Costa Rica. In: Wilson LD, Townsend JH, Johnson JD (Eds) Conservation of Mesoamerican Amphibians and Reptiles. Eagle Mountain Publishing, LC, Eagle Mountain, Utah, 706-715.

Castañeda FE, Mora JM (2015) Kinosternon leucostomum. Sexual Dimorphism. Mesoamerican Herpetology 2(2): 204-205.

Congdon JD, Nagle RD, Dunhan AE, Beck CW, Kinney S, Yeomans SR (1999) The relationship of body size to survivorship of hatchling snapping turtles (Chelydra serpentina): An evaluation of the bigger is better hypothesis. Oecologia 121(2): 224-235. https://doi. org/10.1007/s004420050924

De La Ossa J, Vogt RC, De La Ossa-Lacayo A (2014) Sexo termo dependencia y su relación con la idoneidad en neonatos de Peltocephalus dumerilianus (Testudines, Podocnemididae). Revista de la Asociación Colombiana de Ciencias Biológicas 26: 145-151.

Doody S, West P, Georges A (2003) Beach selection in nesting Pig-nosed turtles, Carettochelys insculpta. Journal of Herpetology 37(1): 178-182. https://doi.org/10.1670/00221511(2003)037[0178:BSINPN]2.0.CO;2 
Dowling Z, Hartwig TS, Kiviat E, Keesing F (2010) Experimental management of nesting habitat for the Blanding's Turtle (Emydoidea blandingii). Ecological Restoration 28(2): 154-159. https://doi.org/10.3368/er.28.2.154

Eggers S, Griesser M, Ekman J (2008) Predator-induced reductions in nest visitation rates are modified by forest cover and food availability. Behavioral Ecology 19(5): 1056-1062. https://doi.org/10.1093/beheco/arn063

Ewert M, Nelson C (1991) Sex determination in turtles: Diverse patterns and some possible adaptive values. Copeia 1991(1): 50-69. https://doi.org/10.2307/1446248

Fernandes Araujo Chaves LP, Viana DC, Chaves EP, Miglino MA, de Sousa AL (2020) Reproductive morphophysiology of the male scorpion mud turtle (Kinosternon scorpioides Linnaeus, 1766) in captivity. Veterinary Medicine and Science 6(3): 570-578. https:// doi.org/10.1002/vms3.245

Ficetola GF, Padoa-Schioppa E, Monti A, Massa R, De Bernardi F, Bottoni L (2004) The importance of aquatic and terrestrial habitat for the European pond turtle (Emys orbicularis): implications for conservation planning and management Canadian Journal of Zoology 82(11): 1704-1712. https://doi.org/10.1139/z04-170

Hartshorn G (1983) Introduction. In: Janzen (Ed.) Costa Rican natural history. University of Chicago Press, Chicago, 119-186.

Higgins K, Oldemeyer J, Jenkins K, Clambey G, Harlow R (1994) Vegetation sampling and measurement. In: Bookhout T (Ed.) Research and management techniques for wildlife and habitats. The Wildlife Society, Baltimore, 567-591.

Hughes EJ, Brooks RJ (2006) The good mother: Does nest-site selection constitute parental investment in turtles? Canadian Journal of Zoology 84(11): 1545-1554. https://doi. org/10.1139/z06-148

Hughes DF, Tegeler AK, Meshaka Jr W (2016) Differential use of ponds and movements by two species of aquatic turtles (Chrysemys picta marginata and Chelydra serpentina serpentina) and their role in colonization. Herpetological Conservation and Biology 11 : 214-231.

Iverson JB (2010) Reproduction in the Red-cheeked Mud Turtle (Kinosternon scorpioides cruentatum) in southeastern Mexico and Belize, with comparisons across the species range. Chelonian Conservation and Biology 9(2): 250-261. https://doi.org/10.2744/ CCB-0827.1

Janzen FJ (1994) Vegetational cover predicts the sex ratio of hatchling turtles in natural nests. Ecology 75(6): 1593-1599. https://doi.org/10.2307/1939620

Janzen FJ, Krenz G (2004) Phylogenetics: which was first, TSD or GSD? In: Valenzuela N, Lance VA (Eds) Temperature dependent sex determination in vertebrates. Smithsonian Institution, Washington DC, 121-130.

Kolbe JJ, Janzen FJ (2001) The influence of propagule size and maternal nest site selection on survival and behavior of neonate turtles. Functional Ecology 15(6): 772-781. https:// doi.org/10.1046/j.0269-8463.2001.00587.x

Kolbe JJ, Janzen FJ (2002) Impact of nest-site selection on nest success and nest temperature in natural and disturbed habitats. Ecology 83(1): 269-281. https://doi.org/10.1890/00129658(2002)083[0269:IONSSO]2.0.CO;2 
Leenders T (2019). Reptiles of Costa Rica: a field guide. Zona Tropical Publications, Ithaca, New York, 625 pp. https://doi.org/10.7591/9781501739545

Litvaitis J, Titus K, Anderson E (1994) Measuring vertebrate use of terrestrial habitats and foods. In: Bookhout T (Ed.) Research and management techniques for wildlife and habitats. The Wildlife Society, Baltimore, 254-274.

Loc-Barragán JA, Reyes-Velasco J, Woolrich-Piña GA, Grünwald CI, Venegas de Anaya M, Rangel-Mendoza JA, López-Luna MA (2020) A new species of mud turtle of genus Kinosternon (Testudines: Kinosternidae) from the Pacific Coastal Plain of northwestern Mexico. Zootaxa 4885(4): 509-529. https://doi.org/10.11646/zootaxa.4885.4.3

López MS, Sione W, Leynaud GC, Prieto YA, Manzano A (2013) How far from water? Terrestrial dispersal and nesting sites of the freshwater turtle Phrynops hilarii in the floodplain of the Paraná River (Argentina). Zoological Sciences (Tokyo) 30(12): 10631069. https://doi.org/10.2108/zsj.30.1063

Manly BFJ, McDonald LL, Thomas DL, McDonald TL, Erickson WP (2002) Resource selection by animals: statistical design and analysis for field studies. $2^{\text {nd }}$ edn. Kluwer Academic Publishers, Dordrecht, 240 pp.

MINAE [Ministerio de Ambiente y Energía] (2002) Resolución Legal R-009-ACA-D-2002. MINAE, Área de Conservación Arenal, Costa Rica.

Mora JM (1989) Eco-behavioral aspects of two communally nesting iguanas and the structure of their shared nesting burrows. Herpetologica 45: 293-298. https://www.jstor.org/ stable/3892884

Morris D (2003) Toward an ecological synthesis: A case for habitat selection. Oecologia 136(1): 1-13. https://doi.org/10.1007/s00442-003-1241-4

Mota Rodrigues JF, Borges-Nojosa DM (2013) Does Kinosternon scorpioides (Linnaeus, 1766) (Testudines: Kinosternidae) prefer to reproduce in clean water? Herpetology Notes 6: 519-521.

Mui A, Edge C, Paterson J, Caverhill B, Johnson B, Litzgus J, He Y (2016) Nesting sites in agricultural landscapes may reduce the reproductive success of Blanding's turtle (Emydoidea blandingii) populations. Canadian Journal of Zoology 94(1): 61-67. https:// doi.org/10.1139/cjz-2015-0154

Oddie MAY, Coombes SM, Davy CM (2015) Investigation of cues used by predators to detect Snapping Turtle (Chelydra serpentina) nests. Canadian Journal of Zoology 93(4): 299-305. https://doi.org/10.1139/cjz-2014-0264

Packard GC, Packard MJ, Miller K, Boardman TJ (1987) Influence of moisture, temperature, and substrate on snapping turtles' eggs and embryos. Ecology 68(4): 983-993. https:// doi.org/10.2307/1938369

Rueda-Almonacid JV, Carr JL, Mittermeier RA, Rodríguez-Mahecha JV, Mast RB, Vogt RC, Rhodin AGJ, de la Ossa-Velasquez J, Rueda JN, Mittermeier CG (2007) Las tortugas y los cocodrilianos de los países andinos del Trópico. Serie de Guías Tropicales de Campo No 6. Conservation Internacional. Editorial Panamericana, Formas e Impresos, Bogotá, D.C., 538 pp.

Savage J (2002) The amphibians and reptiles of Costa Rica. University of Chicago Press, Chicago, 934 pp. 
Scott PA, Glenn TC, Rissler LJ (2018) [2017] Resolving taxonomic turbulence and uncovering cryptic diversity in the musk turtles (Sternotherus) using robust demographic modeling. Molecular Phylogenetics and Evolution 120: 1-15. https://doi.org/10.1016/j. ympev.2017.11.008

Semlitsch R, Bodie R (2003) Biological criteria for buffer zones around wetlands and riparian habitats for amphibians and reptiles. Conservation Biology 17(5): 1219-1228. https://doi.org/10.1046/j.1523-1739.2003.02177.x

Spencer R, Thompson M (2003) The significance of predation in nest site selection of turtles: An experimental consideration of macro- and microhabitat preferences. Oikos 102(3): 592-600. https://doi.org/10.1034/j.1600-0706.2003.12436.x

Steen DA, Gibbs JP, Buhlmann KA, Carr JL, Compton BW, Congdon JD, Doody JS, Godwin JC, Holcomb KL, Jackson DR, Janzen FJ, Johnson G, Jones MT, Lamer JT, Langen TA, Plummer MV, Rowe JW, Saumure RA, Tucker JK, Wilson DS (2012) Terrestrial habitat requirements of nesting freshwater turtles. Biological Conservation 150(1): 121-128. https://doi.org/10.1016/j.biocon.2012.03.012

Strickland J, Colbert P, Janzen FJ (2010) Experimental analysis of effects of markers and habitat structure on predation of turtle nests. Journal of Herpetology 44(3): 467-470. https://doi.org/10.1670/08-323.1

Vogt RC, Flores-Villela O (1992) Effects of incubation temperature on sex determination in a community of neotropical freshwater turtles in southern Mexico. Herpetologica 48(3): 265-270. https://www.jstor.org/stable/3893001

Voves KC, Mitchell TS, Janzen FJ (2016) Does Natural Visual Camouflage Reduce Turtle Nest Predation? American Midland Naturalist 176(1): 166-172. https://doi. org/10.1674/0003-0031-176.1.166

Wilson D (1998) Nest-site selection: Microhabitat variation and its effect on the survival of turtle embryos. Ecology 79(6): 1884-1892. https://doi.org/10.1890/00129658(1998)079[1884:NSSMVA]2.0.CO;2

Wirsing AJ, Phillips JR, Obbard ME, Murray DL (2012) Incidental nest predation in freshwater turtles: Inter- and intraspecific differences in vulnerability are explained by relative crypsis. Oecologia 168(4): 977-988. https://doi.org/10.1007/s00442-011-2158-y

Zar J (1999) Biostatistical Analysis. $4^{\text {th }}$ edn. Prentice Hall, City, New Jersey, 663 pp. 